\title{
KEPERCAYAAN TERHADAP PERPINDAHAN MAKAM DI TANJUNG ${ }^{1}$
}

\author{
Murjani Sani \\ Jurusan Akidah Filsafat Fakultas Ushuluddin dan Humaniora \\ IAIN Antasari Banjarmasin
}

\begin{abstract}
Describing where the moving tomb of Syekh Timur Tengah (hereinafter abbreviated as STT) in Tanjung. The removal of STT was through mediation with the tomb. This tomb is managed to perpetuate the relationship with STT's spirit and the pilgrims. There is 'baulan' tradition in every 14 of Sha'ban, at that time HA is busy to communicate to the STT's spirit, showing his encounter with the spirit of the dead in 'conscious' condition. According to al-Jauri, the alive people can meet the spirit of the dead through dreams/ conscious based on the al-Zumar verse 42. It said that death is not lost but it is the separation of the body with the spirit. Their meeting is based on Ali Imron verse 169-171 when he gets the blessing from Allah and when his brother who livedin the path of His. This is recognized by the Sufism as Liqa Barzakhi, as experienced by al-Tijani, it is out of ratio range. Meeting of HA and STT's spirit is assumed as liqa Barzakhi, although it requires further study.
\end{abstract}

Kata kunci: kuburan, makam, mediator, komunikasi rohani.

\section{Pendahuluan}

Salah-satu kewajiban umat Islam terhadap saudaranya yang meninggal dunia adalah menguburkan². Bagi menjaga kehormatan mait, jarang terjadi pemindahan kubur, kecuali karena wasiat atau pertimbangan memudahkan menziarahi. Kalau pun terjadi pemindahan, hanya antar daerah berdekatan, langka sekali pemindahannya antar pulau apalagi antar negara.

Ternyata pemindahan kubur/makam antar negara ini terjadi di Kalimantan Selatan.Yaitu pemindahan kubur atau makam para Syekh Timur Tengah (selanjutnya disingkat STT) ke Tanjung Kabupaten Tabalong. Menurut pengakuan Penggagas atau Mediator pemindahannya ada ribuan makam/roh yang dipindahkan, meski hanya 48 yang dibuatkan makamnya. Dalam waktu dekat makam Rasulullah dan Khulafa al-Rasyidin juga akan dipindahkan ke daerah ini.

Masalah kubur/makam pindahan dari Timur Tengah ini diakui adanya oleh Tokoh Agama Kabupaten Tabalong. Di antaranya Drs. H. Yazidi Haya, Mantan Kepala Kantor Departemen Agama Kabupaten Tabalong, KH. Ahmad Rasyidi Amin, Lc, Ketua Majelis Ulama Indonesia (MUI) Kabupaten Tabalong, dan Ustadz Aidi Fakhruji (AF) Pegawai Negeri Sipil/Khatib Kabupaten Tabalong. Menurut AF, pada tahun 2000-an alkah yang sekarang berisi bangunan

${ }^{1}$ H. Bahran Noor Haira, Abdullah Karim, H. Murjani Sani (Penulis). Makalah ini diolah dari Hasil Penelitian Tim Fakultas Ushuluddin dan Humaniora IAIN Antasari (2011).

${ }^{2}$ Syekh Muhammad Arsyad al-Banjari, Sabilal Mubtadin li al-Tafaqquh fi Amr al-Din, (Mesir: Dar al-Ihya al-Kutub alArabiyah, tth.), h. 65-82. 
makam para STT ini, mulanya hanya kubur Datu Harung dan dua orang lainnya, sehingga masyarakat mengenalnya 'Alkah Datu Harung'. Namun pada tahun-tahun berikutnya mengalami perkembangan, dijadikan alkah atau makam para STT ini.

Setiap kubur atau makamnya dibuatkan bangunan, bertiang ulin dengan atap seng tanpa dinding. Masing-masing berhias 'kain kuning', menandakan kubur atau makam tersebut 'keramat'. Di dalamnya ditemukan kubur atau makam pindahan dari Timur Tengah ini lengkap dengan nama-namanya, asal daerah, jabatan/pekerjaan mereka ketika masih hidup. Misalnya Makam Syekh Muhammad Ahmad Mekkah, Penjaga Bagian Dalam dan Penutup Ka'bah. Kubur atau makam ini pada waktu tertentu diziarahi masyarakat setempat dan masyarakat lainnya yang datang dari Kabupaten/Provinsi lain.

Pemindahan kubur atau makam STT ini diprakarsai oleh salah seorang warga setempat yang berinisial $\mathrm{H}$. Ariansyah, populer dipanggil $\mathrm{H}$. Asah (selanjutnya disingkat HA). Dia selalu memotivasi masyarakat untuk menziarahi kubur atau makam STT ini karena dinilainya lebih istemewa (afdhal) dan akan mendapat syafa'at Rasulullah. Konteksnya dengan pemindahan ini ketika diwawancarai HA mengatakan bahwa istilah 'pemindahan kubur' harus dibedakan dengan istilah 'pemindahan makam'. 'Pemindahan kubur' yang dipindah adalah roh dan jasadnya sekaligus, sementara 'pemindahan makam' yang dipindah hanya roh saja tanpa jasad, jasadnya tetap di daerah asal. Istilah yang terakhir inilah yang dimaksud dengan 'pemindahan makam' STT ini.

Masalah pemindahan makam STT ini terkuak pertama-kalinya pada acara Babtsu Masail alUmmah IAIN Antasari kerjasama dengan MUI Kabupaten/Kota se Kalimantan Selatan di Tanjung (2010), dan mendapat perhatian serius pihak Fakultas Ushuluddin. Karena itu pada tahun 2011 dilakukan penelitian oleh Tim Fakultas Ushuluddin IAIN Antasari, yang diarahkan pada sejarah keberadaan makam meliputi; asal-usul pemindahan, penggagas/pengelola, tujuan dan motivasi pengelolaan, dan prilaku penziarah. Dan hasil penelitiannya diresume dan diolah kembali menjadi karya tulis ilmiah ini.

\section{Tujun dan Signifikansinya}

Penelitian ini bertujuan untuk mengetahui sejarah keberadaan makam STT di Tanjung Tabalong (pendekatan sejarah). Diharapkan bermanfaat sebagai (i) informasi awal bagi IAIN Antasari dan pihak berkepentingan terhadap fenomena keagamaan di Kalimantan Selatan yang mayoritas penduduknya beragama Islam (ii) bahan dasar kajian lebih lanjut bagi Fakultas Ushuluddin dan Humaniora, Lembaga Babtsu Masail al-Ummah IAIN Antasari, MUI Kalimantan Selatan dan Kabupaten/Kota khususnya MUI Kabupaten Tabalong (iii) sebagai motivasi bagi masyarakat untuk selalu waspada terhadap fenomena yang berkembang termasuk masalah makam pindahan di Kabupaten Tabalong ini.

Yang dimaksud dengan 'keberadaan makam' di sini meliputi asal-usul pemindahan makam, penggagas/pengelola, tujuan dan motivasi pengelolaan, serta prilaku penziarah. 'Syekh' berarti tuan, orang-tua atau guru, jadi yang dikehendaki di sini adalah makam para orang-tua atau guru, bukan makam habib/habaib, yang berasal dari Timur Tengah. 'Timur Tengah' di sini dimaksudkan sesuai dengan yang tertulis di nisan makam, berasal dari Mekkah, Madinah, Irak, Iran, Bagdad, Yaman dan Hadramaut, yang makamnya sekarang ada di Alkah Datu Harung 
Tanjung. Tepatnya terletak di Kelurahan Pembataan RT 3 Kecamatan Murung Pudak Tanjung Kabupaten Tabalong.'Pelaku' adalah Penggagas/Pengelola Pemindahan/Mediator makam STT sekaligus sebagai pengelolanya hingga sekarang.

\section{Metodologi}

Penelitiannya bersifat peneitian lapangan, menggali dan mendeskripsikan informasi terkait keberadaan makam para STT di Tanjung, dengan subjek penelitiannya; penggagas/pengelola perpindahan makam, anggota/pembantunya termasuk penziarah. Objeknya terfokus pada sejarah keberadaan makam para Syekh, dengan data yang diperlukan meliputi; sejarah, asalusul perpindahan makam STT, penggagas/pengelola, pengelolaan, tujuan dan motivasi pengelolaan, serta prilaku penziarah. Sumbernya; penggagas/pengelola dan anggota yang terlibat dalam pengelolaan, Ketua RT dan penziarah. Data dihimpun melalui wawancara dan mengobservasi realita sosial masyarakat penziarah disertai mewawancarainya.Penelitiannya bersifat non-hipotesis, sehingga tidak memerlukan rumusan hipotesis.Hal ini terkait langsung dengan tujuan penelitiannya yang hanya menggambarkan keberadaan makam para STT yang dipindah ke Tanjung tersebut. Data kualitatifnya digambarkan dengan kata-kata atau kalimat menurut kategorinya bagi memperoleh kesimpulan.

\section{Profil Lokasi}

Tanjung Kabupaten Tabalong terletak di Utara Kalimantan Selatan. Sepuluh tahun terakhir daerah ini berkembang pesat di berbagai bidang di bawah pimpinan Bupatinya (Drs. H. Rachman Ramsyi, M.Si).Infra struktur seperti jalan raya khususnya di Mabuun Raya berkembang menjadi empat jalur. Di awal tahun 2011 dipancangkan tiang pertama pembangunan Islamic Center di atas tanah 4 (empat) hektar persegi. Tahun 2013 yang lalu sudah diresmikan oleh Gubernur Kalimantan Selatan. Direncanakan, semua kegiatan keagamaan di daerah ini dipusatkan di Islamic Center ini sesuai Motto Daerahnya 'Terwujudnya Masyarakat Tabalong yang Sehat, Cerdas dan Sejahtera Berbasis Agama'.

Kabupaten ini terdiri dari 9 (sembilan) Kecamatan, masing-masing; Kecamatan Tanjung, Upau, Haruai, Tanta, Muara Harus, Kelua, Pugaan, Banua Lawas dan Kecamatan Murung Pudak. Khusus Kecamatan Murung Pudak terdiri dari 4 (empat) Kelurahan dan 6 (enam) Desa. Masing-masing Kelurahan Belimbing Raya, Belimbing, Mabuun dan Kelurahan Pembataan. Keenam desanya masing-masing; Desa Sulingan, Maburai, Kapar, Masukau, Kasiau dan Kasiau Raya. Makam ST'T yang menjadi sasaran penelitian ini terletak di wilayah Rt 3 Kelurahan Pembataan Kecamatan Murung Pudak.

Kelurahan Pembataan dipimpin Lurahnya, H. Sutopo yang baru dua tahun bertugas sebagai Lurah di sini (2011). Kantor Kelurahannya terletak di Jl. Anggrek I dekat Simpang Tiga menuju Murung Pudak dan Komplek Pertamina, berseberangan dengan Komplek Perumahan Dinas Bupati Tabalong. Kelurahan Pembataan ini berbatasan; sebelah Utara dengan Kelurahan Belimbing Raya, sebelah Selatan dengan Desa Tanta, sebelah Timur dengan Desa Sulingan, dan sebelah Barat dengan Kelurahan Mabuun.

Kelurahan ini makin berkembang karena terletak dan termasuk bagian dari Pusat Perkotaan Kabupaten Tabalong.Berpenduduk 7.460 jiwa dengan pencaharian warganya beragam; Petani, 
Swasta, Pegawai Negeri Sipil dan Pejabat. Pendidikan warganya juga beragam: SD, SMP/ sederajat, SMA/sederajat, D2, D3, Sarjana S1 dan S2. Dipredeksikan bahwa Sumber Daya Manusia (SDM) Kelurahan ini cukup potensial dan berprospek untuk dikembangkan. Didukung adanya lembaga pendidikan formal dan non formal seperti TK, SD/sederajat, SMP/sederajat dan Perguruan Tinggi Swasta. Yang non formal seperti pendidikan melalui sarana tempat ibadah, di rumah tangga, melalui Taman Pendidikan al-Qur'an, Persatuan Burdah/Maulid al-Habsyi, Remaja Mesjid dan sebagainya.

Sebagian besar penduduknya beragama Islam (7.272 orang), hanya sedikit yang non muslim; Kristen 162 orang dan Hindu, 26 orang. Kefanatikan beragama masyarakat terkesan kental sekali; rajin shalat dan menghadiri pengajian atau majelis taklim sebagai bahan dasarnya. Di kelurahan ini ditemukan sejumlah tempat ibadah; 2 buah mesjid dan 6 buah langgar, seluruhnya dimanfaatkan untuk kegiatan ibadah shalat fardhu, shalat tarawih, kegiatan PHBI, Nisfu Sya'ban, pembacaan Shalawat Burdah/Maulid al-Habsyi dan lain-lain. Tempat ibadah non muslim tidak ada, karena itu mereka yang non muslim beribadah di gereja atau pura terdekat di luar kelurahan.

Aktivitas keagamaan ini melahirkan suasana kondusif keagamaan dan kebersamaan. Itu pula yang membuat warganya sadar lingkungan dan memahami arti perlunya kesalehan sosial. Kalau pun ada gejala atau fenomena berupa 'benih-benih gesekan' yang membawa kepada kemungkinan ketidak-rukunan, segera diatasi dan dicarikan jalan ke luarnya oleh Tokoh Agama/ Tokoh Masyarakat. Akhirnya hingga sekarang tidak pernah ada benturan pemikiran apalagi benturan fisik antar warga dan pemeluk agama. Dengan demikian maka kebersamaan dan kerukunan antar umat beragama, antar umat beragama dengan pemerintah dan antar intern umat beragama di kelurahan ini terjadi dan mewarnai masyarakat.

\section{Penyajian Data}

\section{Asal-Usul Makam}

Alkah makam ST'T yang dipindah ke Tanjung ini mulanya dikenal 'Alkah Datu Harung', karena yang berkubur di sini pertama kalinya adalah 'Datu Harung', menyusul dua orang datu lainnya masing-masing Datu Rambut Panjang (Raudhah) dan Datu Ranggas. Sejak tahun 1980an ketiga kubur ini selalu diziarahi karena dianggap kubur 'keramat' di Kelurahan Pembataan ini.

Namun sejak tahun 2000-an hingga sekarang Alkah 'Datu Harung' ini mengalami perkembangan, atas prakarsa HA. Sehingga menurut pengakuannya, Kubur Datu Harung cs. tersebut secara fisik-rohani sudah dipindahnya ke suatu tempat antara surga dengan neraka. Sekarang ini yang ada di alkah tersebut hanya makam para Syekh pindahan dari Timur Tengah atas kehendak mereka sendiri melalui mediasinya. Mereka berasal dari Mekkah, Madinah, Bagdad, Iran, Irak, Yaman dan Hadramaut. Selain makam-makam tersebut ada 6 (enam) buah kubur keluarga HA sendiri, masing-masing almarhum H. Rusdi Halim, Hj. Siti Zubaidah SE, Jumarin bin Nojokarto, dan ada 3 (tiga) kubur lainnya yang tanpa nama.

Menurut HA selaku Penggagas/Pengelola/Mediator Pemindahan, bahwa istilah 'kubur' harus dibedakan dengan istilah 'makam'. Kubur' adalah tempat penguburan orang mati yang di situ ada jasad dan rohnya.Sementara 'makam' adalah tempat roh orang mati yang jasadnya tetap di daerah asal. Rohnya dipindah sekaligus dimakamkan di sini berdasar permintaan mereka 
sendiri melalui komunikasi rohani dengan HA. Dengan demikian maka 'pemindahan makam' para STT itu dimaksudkan adalah pemindahan 'roh' secara rohani, tanpa diikuti dengan pemindahan jasadnya, jasadnya tetap di Negara asalnya.

Menurut HA, permohonan agar makamnya dipindah dan dimakamkan di sini banyak sekali, sebagian diterimanya dan sebagian ditolak. Yang diterima ribuan orang namun yang ada bangunan makamnya hanya para pemimpinnya. Yang ditolak lebih banyak dari itu, di antaranya adalah rombongan dari Provinsi Nangroe Aceh Darussalam karena kedatangannya dinilai HA lancang dan tidak memperhatikan etika kesufian. Mereka menerima penolakan ini dengan lapang-dada. Menurut HA hingga sekarang pun masih banyak yang memohon untuk dimakamkan di sini. Dikatakan bahwa setelah kubur Datu Harung cs. dipindahkan, datanglah Syekh Muhammad Ahmad Mekkah memohon agar dimakamkan di sini, dengan harapan dapat diziarahi 2 (dua) kali dalam seminggu. Syekh Muhammad Ahmad ini sebenarnya adalah Datu Sanggul (Datu Tuha) yang HA sendiri diakuinya sebagai adiknya secara rohani. Keinginannya dikabulkan, dibelilah tanah bagi perluasan alkahnya. Di kiri-kanannya ada dua buah pohon sebagai simbol gerbang dunia-akhirat. HA mengaku punya kemampuan mempertemukan seseorang secara rohani dengan Nabi Muhammad saw. yang dianggapnya 'Datu Tertua' di alam rohani. Turunan asli Rasulullah ada lima katanya; masing-masing Ahmad, Syekh Rahmat Syihab Akbar bin Ahmad, Syekh Ali Mas'ud Daud Rachman Salam al-Syihab, Syekh Abdul Qadir Jailani dan Syekh Hasan. Syekh Ali Mas'ud Daud Rahman Salam al-Syihab adalah nama asli Datu Sanggul.

Pencipta alam ini adalah Allah, Dia pula yang mencipta Ahmad (Nur Muhammad) yang melahirkan Syekh Rahman Salam al-Syihab dan Syekh Abd. Qadir Jailani. Inilah turunan Nabi yang sebenarnya. Menurut pengakuan HA, dari Nabi Muhammad saw. menyusul Datu Sanggul dan keturunannya, hingga terwujud makam secara rohani di Tanjung Kabupaten Tabalong ini. Dengan demikian dapat dikatakan, bahwa asal-usul makam ST'T di Tanjung ini tidak terpisah dengan kedatangan Datu Sanggul yang turut bermakam di wilayah ini.

Dikatakan bahwa para STT ini mulai bermakam di daerah ini sejak tahun 2000. Roh mereka disucikan, sebagai syarat masuk surga, inilah firqab najiah (kelompok yang selamat) ujar HA. Hingga sekarang tidak kurang dari 650.000 orang Syekh yang makam (dalam hal ini adalah rohnya) dipindah ke sini, termasuk 200.000 orang yang baru diizinkan, dan semuanya dianggap 'basahabat dengannya. Setiap tanggal 14 Sya'ban diadakan acara 'Haulan' di makam ini. Untuk yang kesepuluh kalinya diadakan bertepatan pada hari Jum'at 14 Sya’ban 1432 H/16 Juli 2011, dihadiri sejumlah besar masyarakat.

\section{Bangunan Makam}

Di alkah ini terdapat 23 bangunan makam persegi empat dengan ukuran yang berbeda, 1 x 2 m hingga 10 x 15 m, seluruhnya berisi 48 buah makam pimpinan STT. Yang berukuran 10 x 15 m adalah tempat khusus untuk berdo'a, dilengkapi sarana untuk wudhu dan ruang istirahat. Masing-masing bangunan berisi 1-10 makam, dan ada 6 makam tanpa bangunan, ia hanya berupa pancangan segi empat bertiang besi kecil. Seluruh bangunannya beratap seng tanpa dinding namun berhias kain kuning, kecuali 'makam utama' selain berhias kain kuning juga diberi pagar kawat dan terkunci. Makam berhias kain kuning ini menurut warga setempat dianggap sebagai 
kubur atau makam 'keramat'.

Bangunan 1 berukuran 2 x 2 m berisi makam Pengeran Singa Terbang Hadramaut (Habib Abd. Wahab bin Bakar) Ahli Kunjungan.Bangunan 2 berukuran 4 x $4 \mathrm{~m}$ berisi makam Syekh Rahmat Ali Madinah, Penjaga Mimbar Mesjid Nabawi. Bangunan 3, 2 × 2 m, berisi makam Pangeran Surya Negara Hadramaut (al-Harun bin Habsyi) Ahli Pasukan Perang. Bangunan 4, 5 x 6 m. merupakan 'bangunan utama' ada 4 makam di dalamnya: Makam Syekh Muhammad Ahmad, Penjaga Alam dan Penutup Ka'bah. Syekh Baharun Irak, Penjaga Makam Ismail. Habib al-Idrus Madinah, Penjaga Hajar al-Aswad.Habib al-Ali bin Hasyim Madinah, Penjaga Ka'bah Shaf Pertama. Bangunan 5, 4 × 6 m, berisi makam Syekh Rachman Alwi bin Bakar Madinah, Pengawas Mesjid Nabawi. Bangunan 6, 3 x 4 m berisi makam Syekh Abd. Manan al-Syihab Madinah, Pangeran Badai Gurun dan Penjaga Mesjid Nabawi. Bangunan 7, berupa 14 bentuk segi empat beratap kain kuning tiang besi berukuran $1 \times 3$ meter, ttidak ada makam di dalamnya. Bangunan 8, 4 x 5 m berisi empat makam; Syekh Arif Rusman Abd. Ghani Hadramaut, Ahli Fiqh Tauhid Tasawuf. Syekh Rachman Siddiq, Syekh Ahd Siddiq, Syekh Zailani (ketiganya dari Iran). Bangunan 9, 4 x 4 m, berisi tiga makam; Syekh Rusman Awaluddin Said Mekkah, Khatib/ Imam Mekkah. Syekh Rahmat Ali Usman Madinah, Imam Mesjid Nabawi dan Syekh Hasbullah Iran. Bangunan 10, 3 × 3 m, terdapat 1 makam, yaitu Syekh Mustakim Said Singa Padang Padir Madinah. Bangunan 11, 5 x 7 m, terdapat tiga makam; Syekh Abdullah Muksin Madinah, Penjaga Pintu Kiri Makam Rasulullah, Syekh Ali Usman al-Hasyim Madinah, Penjaga Pintu Kanan Makam Rasul, Syekh Abd. Manan bin Bakar al-Hasyim. Bangunan 12, 5 x 6 m berisi empat makam; Syekh Abdullah Salim al-Hasyim Madinah, Penjaga Sumur Zamzam, Syekh Abdullah Ali bin Abbas Madinah, Bilal Mesjid Nabawi, Syekh Zamaluddin al-Zailani Mekkah, Penjaga Sebelah Kiri Hajar al-Aswad. Syekh Ja'far Umar Madinah, Imam Mesjid Madinah. Bangunan 13, 2,5 x 12 m, berisi delapan makam; Habib Rasyid Rachman bin Abbas Madinah, Bilal Mesjid Nabawi. Syekh Abdullah Alwi bin Abbas Mekkah, Imam Besar Mekkah. Habib Bakar al-Husin Iran, Ahli Tasawuf. Habib al-Husin al-Said Irak, Ahli Tasawuf. Syekh Abdurrachman Madinah, Penerima Tamu dan Penjaga Mesjid Nabawi. St. Raudhah al-Rasyid Mekkah, Syekh Zein al-Hasyim Irak, Saudagar Kaya.Syekh Rachman Said al-Harun, Saudagar Kaya. Bangunan 14, 4 x 5 m berisi empat makam; Habib Ahmad Rachman Bagdad dan Habib Abdullah Said Bagdad, keduanya utusan Syekh Abd. Qadir Zailani. Habib Rachman Mas'ud Madinah, Habib Rachman Alwi Mas'ud Madinah, keduanya utusan Syekh Muhammad Samman al-Madani. Bangunan 15, $3 \times 3$ m, berisi makam Pangeran Nusa Pati (al-Hamid bin al-Qatri), Ahli Perang. Bangunan 16, $10 \times 12$ m merupakan bangunan terbesar dimakam ini, khusus untuk tempat upacara dan berdo'a. Di sampingnya ada makam Syekh Rachmat Guzali Madinah, Ahli Pengumpul Do'a.Di bangunan ini ada ruang wudhu dan istirahat.Ia juga digunakan sebagai tempat upacara tertentu seperti 'Haulan'. Bangunan 17, 2 × 2,5 m tanpa makam kecuali di depannya ada Makam Syekh Rahmat Guzali dari Madinah Ahli Pengumpul Do'a. Bangunan 18, 2,5 x 10 m di dalamnya ada 10 makam; Habib al-Husin Hadramaut, Dokter Ketua Penanganan Penyakit Berat). Habib al-Haddad Hadramaut, Dokter Keliling.Syekh Hasan alWahid Iran, Dokter Spesialis.Habib Amir al-Husin Hadramaut. Habib Zamaluddin Hadramaut. St. Hamdah Ramlah al-Husin Hadramaut, Puteri Tiga Wajah.Habib Rachman al-Husin Hadramaut. Habib Said al-Husin dan Habib Zamali al-Husin, keduanya dari Hadramaut. 
Bangunan 19, 1,5 x 1,5 m makam Pangeran Kartapati Hadramaut (Zulfikar), Ahli Strategi. Selain itu ada enam kubur masyarakat biasa tanpa bangunan dari keluarga HA sendiri.

\section{Penggagas dan Anggota}

Tidak ada struktur organisasi bagi pengelolaan makam ST'T ini.Misalnya adanya Penasehat, Ketua, Sekretaris, Bendahara dan Anggota. Kecuali adanya Penggagas atau Pengelola, Penjaga atau Pembantunya. Selaku Penggagas, Pengelola, Mediator sekaligus sebagai Penjaga makam adalah HA sendiri.Ia dinilai punya kharisma tersendiri di mata Pembantu/Anggotanya. Karena itu menurut HR (Pembantunya) tidaklah sembarang orang bisa menemui HA ini.

Ia berasal dari Amuntai HSU, lahir tahun 1950, anak dari pasangan Syahrani Kadar dengan Siti Aisyah. Latar-belakang pendidikannya; SD, SMP, SMA dan sempat empat semester Kuliah di Fakultas Ekonomi Universitas Lambung Mangkurat (Unlam) Banjarmasin. Karena terbentur masalah ekonomi, maka ia berhenti dan kembali ke daerah asalnya.

Menurutnya, di usia SD-nya ia diajari 'Ilmu Dalam' sambil 'mangaji duduk' di kampung. Di usia dewasanya pindah ke Tanjung, hingga sekarang (2011) sudah berusia 61 tahun, namun tampak masih segar dan 'terkesan' awet muda, meski diakuinya kalau ia sudah tua secara rohani. Yang cukup menarik antara lain adalah bahwa kalau ia berceritera terkait nama-nama Syekh di alam rohani sulit untuk dihentikan.

Suatu saat HA melamar bekerja di Perusahaan Minyak Pertamina Murung Pudak. Setelah diterima ia pun bekerja penuh disiplin hingga masa pensiun. Tinggal di Komplek Pertamina Jl. Semangka Blok II Rt 20 No. 9a Murung Pudak Tanjung. Rumahnya cukup besar, terbuat dari bahan kayu. Hidup bersama isteri dan tiga orang puteranya. Yang bungsu masih sekolah SD, dan menurutnya anak bungsunya inilah yang nantinya akan mewarisi ilmu dan menggantikannya. Di bagian belakang rumahnya ada ruang istirahat, di sinilah sore-sore HA santai sambil menerima tamu. Di bagian kiri depan rumahnya ada sumur agak luas, tempatnya memelihara puluhan burung belibis kesukaannya.

HA punya kemampuan 'basahabat' dengan roh halus/roh gaib, bisa batatambaan pulasit dan yang sejenisnya. Ia mengaku badangsanakan dengan sejumlah tokoh-tokoh sufi di alam gaib. Syekh Abdul Qadir Jailani diakuinya adik dalam persahabatan. Syekh Samman al-Madani diakuinya murid. Ia juga mengaku ahli hisab (ahli menghitung awal dan akhir bulan) dan mengetahui peristiwa yang akan terjadi, seperti dunia akan kiamat. Bila kiamat ujarnya, umat akan menyatu dengan kami, yang di neraka akan masuk surga. Mengaku bertemu Rasulullah setiap saat melalui sinar-sinar, inilah yang disebutnya 'laisa kamitslihi syai'un', 'lam yazuq lam yadri. Rasulullah itu putih kemerah-merahan dan tinggi semampai, dunia ini dari nur-nya. Nabi Muhammad saw. itu tidak sependirian dengan sahabat utamanya; Abubakar al-Shiddiq, Umar bin Khattab, Usman bin 'Affan dan Ali bin Abi Thalib, kecuali sependirian dengan HA. Malaikat Jibril menurutnya pernah menemuinya dan berkata; siapa yang berdo'a malam ke 13, 14, 15 Sya'ban, do'anya akan dikabulkan. Inilah anugerah padaku, ujar HA yang membuatku sedikit agak tahu dibanding orang lain melalui Asma al-Husna-Nya. Orang-orang ujar HA hanya tahu 'nama' saja, padahal jika Allah itu mengambil tempat, maka hal itu bukanlah Dia yang sebenarnya.

Menurut pembantunya, ketika acara Haul ke X 14 Sya'ban 1432 yang lalu, hadir sekitar 500-an orang, berasal dari masyarakat setempat, ditambah dengan warga yang datang dari 
Kabupaten Hulu Sungai Utara dan Kabupaten Balangan (Paringin). Menurutnya, HA ketika itu tidak banyak terlibat dalam acara 'Haulan' ini, karena ia sibuk menerima 500.000-an tamu gaib dari berbagai penjuru dunia. Menurut HR, ketika itu HA 'ngomong' sendirian dengan isyarat-isyarat tertentu yang mengesankannya sedang berkomunikasi rohani dengan roh gaib. Ketika ditanya terkait kehadiran masyarakat dalam haulan itu, HA mengaku dihadiri sekitar 500-an orang, dengan catatan belum terhitung yang tidak kelihatan di alam gaib. Dikatakannya, Presiden Republik Indonesia yang Pertama (Bung Karno) juga hadir secara rohani meski pun tidak diundang dan tidak tergolong wali. Begitulah ujar HR yang membuat masyarakat menganggapnya sebagai orang yang mempunyai kharismatik tersendiri. Sehingga tidak setiap orang yang menamu diterimanya, apalagi ketika dia sedang berkomunikasi dengan roh gaib.

Menurut Pembantunya HA termasuk orang kaya yang dermawan, menanam saham di PT. Adaro Tanjung yang bergerak di bidang batubara. Karena itu maka biaya keperluan makam; mulai dari pemeliharaan kebersihan, acara haulan, penggantian kain kuning, sepenuhnya berasal daripadanya. Sekarang ini dia sedang membangun rumah permanen di Jl. Pangeran Muhammad Noor Tanjung, berdekatan dengan Komplek Perumahan Dinas Bupati Tabalong. Di bangunan rumah ini disiapkan ruang praktik anaknya yang akan selesai studi di Fakultas Kedokteran Spesialis Tulang. Di bagian atasnya ada bangunan kecil, yang menurut anaknya direncanakan menjadi tempat khalwat ayahnya (HA). Anggota/Pembantu pengelolaan makam STT itu hanya dua orang, masing-masing H. Raji (HR) dan H. Sarjono (HS). Keduanya tinggal berdekatan dengan alkah makam STT ini.Keduanya mengaku tidak banyak tahu tentang sejarah Alkah Datu Harung cs konteksnya dengan makam para ST'T ini.Yang sangat mengetahui tentang hal itu katanya adalah HA sendiri selaku Penggagas/Pengelola dan Mediator perpindahannya.

\section{Tujuan dan Motivasi}

Di atas digambarkan bahwa Penggagas makam STT di Tanjung ini adalah HA dengan kondisi ekonominya yang cukup 'memadai'. Hal ini mengesankan bahwa dia tidak mengharapkan bantuan pihak lain konteksnya dengan pembiayaan makam. Di samping sebagai 'Penggagas' juga berperan sebagai Pengelola di lapangan. Dalam pengelolaannya tidak mengharapkan bantuan orang lain, malah biaya pemeliharaan kebersihan sepenuhnya berasal daripadanya. Ketika ditanya tujuan pengelolaan, ia mengatakan (i) semata-mata untuk kelanggengan hubungan dengan roh para STT yang ada di makam. Karena yang mau pindah dan bermakam di sini adalah roh para STT itu sendiri (ii) Kecuali itu Pemerintah Kabupaten Tabalong memiliki tambahan tempat wisata religi selain yang sudah ada di Desa Binturu Kecamatan Kelua, yaitu Makam Syekh Muhammad Nafis al-Banjari.

Menurut teori ekonomi, aktivitas apa pun tidak lepas dari motivasi ekonomi, apalagi pengelolaan makam sebesar dan seluas itu dengan berbagai keperluannya. Namun konteksnya dengan pengelolaan makam para STT di Tanjung ini berbeda dengan teori tersebut. Karena berdasar informasi dan kenyataan, tidak ditemukan indikasi ke arah sana. Di alkah makam para Syekh maupun di jalan-jalan menuju alkah makam dan di mana pun, tidak ditemukan adanya celengan atau 'kotak amal' yang hasilnya untuk kepentingan pengelolaan makam ini. Begitu juga tidak ditemukan data kemungkinan menyurati orang 'tertentu' untuk meminta derma atau sumbangan bagi kepentingan hal tersebut. 
Kenyataan menunjukkan bahwa pembiayaan keperluan alkah makam para ST'T seluruhnya dari dana pribadinya. Hal ini dilakukannya semata-mata karena Allah (ikhlas) dan demi mengayomi roh-roh para Syekh di makam tersebut. Saya ujar HR selaku Pembantunya, bila 'kekurangan dana bagi keperluan pengelolaan, melapor langsung kepada HA, ia pun memberikan sesuai keperluan'. Ketika dinding bangunan makam kelihatan kurang baik dan tampak mulai rusak dan perlu diganti, saya pun kata HS Pembantunya segera melaporkan kepadanya dan langsung mendapat respon positifnya. HA pun memberikan dana sesuai keperluan'. Saya kata HR lagi, tidak sekali-dua meminta dana untuk kepentingan pribadi, ternyata HA pun tidak keberatan memberinya.

Ziarah kubur menjadi budaya masyarakat Kalimantan Selatan termasuk masyarakat Tanjung Kabupaten Tabalong.Hal ini sebagai bukti kefanatikan mereka dalam beragama. Islam mengajarkan ziarah kubur: Kuntu nabaitukum 'an ziarat al qabr fazûruba (Aku melarang kalian ziarah kubur, kemudian aku memerintahkannya). Dilarang ketika akidah umat masih lemah, dan begitu sudah kuat diperintahkan menziarahinya.Rasul menziarahi kubur ibunya, mendo'akan keampunan dosa baginya. Akhirnya beliau mengajak umatnya ziarah kubur karena mengingatkan akan kematian (tazkirah li al-maut). Karena itu masyarakat muslim pada umumnya tidak segan mengorbankan waktu tenaga dan dana untuk kepentingan ziarah kubur ini. Pada kesempatan Idul Fitri, Idul Adha dan lainnya termasuk ziarah ke makam STT yang ada di Tanjung Tabalong ini.

Kenyataan menunjukkan bahwa makam-makam ini diziarahi masyarakat setempat dan ada juga yang datang dari luar Kabupaten Tabalong, seperti dari Kabupaten HSU, Balangan dan dari Provinsi Kalimantan Timur. Dikatakan, bahwa setiap hari ada penziarah yang datang, terutama pada hari Jum'at siang. Khusus penziarah yang datang dari luar daerah kabupaten, biasanya mereka ziarah sekaligus menghadiri acara 'Haulan' makam ST'T yang diadakan setiap Tanggal 14 Sya'ban. Setelah acara 'Haulan' selesai mereka langsung menziarahi makam para STT tersebut.

Prilaku masyarakat saat menziarahinya, tidak tampak adanya prilaku yang 'aneh-aneh' alias yang menyimpang. Setibanya di makam, mereka duduk dalam posisi menghadap matahari terbit membelakangi kiblat, seakan berhadapan langsung dengan yang diziarahi. Lalu membaca surat Yasin, surah al-Ikhlas, surah al-Mu'annizatain, kemudian bertahlil, dan ditutup dengan pembacaan do'a, diniatkan pahalanya untuk almarhum. Setelah itu mereka ke makam lain untuk melakukan hal yang sama. Bagi yang membawa kembang diletakkan di nisan makam.

Terkait dengan kondisi atau sikap hati penziarah saat itu menurut AF, tergantung masingmasing individu penziarah dan Allah sajalah yang mengetahuinya. Meskipun menurut HR, ketika ziarah mereka sering mengalami kerasukan roh halus yang populer disebut dengan istilah 'Kasarungan atau kasurupan'. Ketika itu suaranya berubah dan omongannya menjadi 'tidak nyambung' dan tidak bisa dipahami bila dilakukan komunikasi dengannya. Namun setelah diberi 'air tawar' (tawar sapubun) berupa air yang dibacakan do'a tertentu oleh HA, maka kondisi penziarah tersebut menjadi normal kembali. Memang menurut HR, Penggagas/Pengelola makam STT, yang dalam hal ini adalah HA sendiri berteman (basababat) dengan roh halus/roh gaib, sehingga ia dapat melakukan komunikasi dengannya. Konteksnya dengan hal tersebut ia

\footnotetext{
${ }^{3}$ Imam Muslim, Shabih Muslim, Juz I, (Bandung: Syirkah al-Ma'arif li al-Thaba' wa al-Nasyr, tth.), h. 389.
} 
bisa memberi banyu tawar untuk menolak gangguan roh halus/roh gaib yang mengganggu penziarah. Itulah sebabnya masyarakat juga mengenal bahwa HA Penggagas/Pengelola/ Mediator pemindahan makam STT ini sebagai seorang 'pananambaan' terhadap masyarakat yang diganggu atau 'karasukan' roh halus/roh gaib seperti di atas.

Jadi dari segi penziarah tidak ditemukan adanya prilaku menyimpang ketika mereka menziarahi makam para ST'T ini, meski pun kondisi atau sikap hatinya tergantung individu masing-masing. Bila sejalan dengan ketentuan agama maka bermanfaatlah ziarahnya. Bila menyimpang dari ketentuan maka resikonya menjadi tanggung-jawabnya sendiri. Meski demikian, pihak berwenang terutama tokoh agama dan tokoh masyarakat tetap harus membekalinya dengan ilmu agama atau pengetahuan ke-Islaman bagi mengantisipasi kemungkinan adanya penyimpangan.

Makam pindahan yang ceritera asal-usulnya seperti digambarkan di atas, tidak banyak diketahui masyarakat Kelurahan Pembataan termasuk masyarakat kelurahan lainnya di Kecamatan Murung Pudak Tanjung. Seperti masyarakat Kelurahan Belimbing, Kelurahan Belimbing Raya dan Kelurahan Mabuun. Hal ini terbukti ketika ditanyakan, salah-satunya kepada pemilik Hotel tempat menginapnya tim (posisi Hotel termasuk wilayah Kelurahan Pembataan). Mereka ‘terkesan' kaget terhadapnya, apalagi setelah mendengar asal-usul makam STT demikian. Itulah sebabnya menurut AF, tidak ada tanggapan serius mereka terhadap masalah pemindahan makam STT ke wilayah ini. Dikatakannya bahwa masyarakat di sini lebih fokus pada pekerjaan sehari-hari bagi mencukupi nafkah hidup keluarganya. Mereka 'lihat-tiring' saja, dalam arti tidak peduli terhadap perkembangan lingkungan termasuk dengan keberadaan, sejarah dan asalusul makam ST'T di Kelurahan Pembataan ini.

Kondisi ini diperkuat lagi dengan informasi Modin (Ketua RT 1 Kelurahan Pembataan) yang tinggal berdampingan dengan alkah makam para STT. Masyarakat katanya 'kada tabumanabu' dengan aktivitas di makam, kecuali membantu menunjukkan posisi lokasinya bagi penziarah baru, membantu pelaksanaan acara 'selamatan' yang dilaksanakan penziarah. Sekalisekali memimpin membacakan do’anya. Karena itu ujarnya, keberadaan makam ST'T ini tidaklah menjadi masalah bagi masyarakat sekitar konteksnya dengan agama dan sosial. Makam itu biasa saja, malam hari gelap sebagaimana alkah lainnya. Siang hari terutama hari Jum'at baru ada yang menziarahinya.

Dalam Babtsu Masail al-Ummah IAIN Antasari kerja sama dengan MUI Kabupaten/Kota se Kalimantan Selatan di Tanjung beberapa waktu yang lalu, Ketua MUI Kabupaten Tabalong mengangkat masalah ini dengan mengatakan; bahwa akhir-akhir ini banyak hal yang 'anehaneh', di antaranya di Tanjung Kabupaten Tabalong sendiri. Sekarang katanya, sudah ada makam para STT di daerah ini yang dipindah oleh 'orang tertentu'. Dalam waktu dekat katanya, akan dipindah lagi, makam Khulafa al-Rayidin (Abubakar, Umar, Usman dan Ali bin Abi Thalib) bersama isteri-isteri Rasulullah. Terkait hal ini menurut AF, MUI setempat berpendapat tidak menjadi masalah selama tidak ada protes menyimpang terhadapnya.

\section{Analisis}

Istilah 'pemindahan kubur' menurut HA harus dibedakan dengan 'pemindahan makam'. 'Pemindahan kubur' adalah pemindahan kubur mait ke alkah lain lengkap dengan jasadnya. 
Sementara 'pemindahan makam' adalah pemindahan kubur secara rohani, dengan catatan jasadnya tetap berada di daerah asal. Pengertian kedua inilah yang dimaksud dengan 'pemindahan makam' para STT di Kabupaten Tabalong Tanjung. Dalam arti rohnya dipindah ke daerah ini sementara jasad atau fisiknya tetap berada di daerah asal (Timur Tengah).

Dalam proses pemindahan HA berperan sebagai mediator melalui komunikasinya dengan roh para Syekh. Hal ini sesuai pengakuan HA sendiri, bahkan menurutnya masih banyak yang menemuinya memohon untuk dipindah bermakam di sini, sebagian diterima dan sebagian ditolaknya. Termasuk 500.000 roh para Syekh yang hadir pada Haul ke X 14 Sya'ban 1432 H/ 2011 memohon untuk dimakamkan di sini juga ditolak. Menurut HR, dalam setiap acara Haulan, HA mengambil ruangan tertentu untuk berkomunikasi dengan roh para STT itu. Hal ini mengisyaratkan HA bertemu dengan roh orang-orang yang sudah meninggal dunia dalam keadaan jaga(yaqazhah).

Dalam Kitabal-Ruh Libni al-Qayyim karya Imam Syamsuddin Abi Abdillah bin Qayyim alJauzy disebutkan, bahwa roh orang hidup bisa bertemu dengan roh orang yang sudah mati melalui mimpi atau jaga ${ }^{4}$. Hal ini menurut al-Jauzy didasarkan firman Allah dalam Surah alZumar ayat 42, bahwa manusia yang mati dan tidur, rohnya dipegang Tuhan. Roh orang mati dipegang-Nya dan roh orang tidur dikembalikan-Nya hingga dapat bangun kembali. Berdasar hal ini dapat dipahami bahwa kematian bukan berarti lenyap sama sekali, melainkan sekedar perpisahan tubuh dengan roh yang menjadi pokok kehidupan di dunia ${ }^{5}$.

Terkait dengan firman Allah surah Ali 'Imran 169-171 Ibnu Qayyim al-Jauzy mengatakan bahwa roh bisa bertemu dalam tiga bentuk: (i) ketika memperoleh rezeki di sisi Tuhan (ii) ketika bertemu dengan saudaranya yang hidup dan berjuang di jalan Allah, melalui mimpi atau lainnya (iii) ketika bertemu saling bergembira satu sama lain ${ }^{6}$. Abdullah bin Mubarak berkata; Aku pernah bermimpi bertemu Sufyan al-Tsauri yang sudah meninggal dunia. Aku bertanya kepadanya; Apa yang diperbuat Tuhan kepadamu? Dia menjawab; Kini aku telah bertemu dengan Rasul dan golongannya. Terkait ayat 169-171 surah Ali 'Imran ini Abu Abdillah bin Munaddih, dari ceritera Abdullah bin Sulaiman berkata; Telah sampai kepadaku bahwa roh orang hidup dengan roh orang mati saling bertemu dan berdialog antar mereka terkait peristiwa masa lalu sekarang dan yang akan datang. ${ }^{8}$ Berdasar uraian di atas dapat dipahami bahwa roh orang hidup bisa bertemu berbicara dan berdialog dengan roh orang yang sudah meninggal dunia baik melalui mimpi atau melalui cara lainnya. Kalau demikian halnya maka apa yang dialami HA (Penggagas/Pengelola pemindahan makam para STT di Tanjung) yang mengaku dapat berhubungan dengan roh mereka yang bermakam di Kelurahan Pembataan Tanjung tersebut 'serupa dan mirip' dengan peristiwa ini.

Pertemuan roh orang yang masih hidup dengan roh orang yang sudah meninggal dunia demikian, dialami oleh tokoh-tokoh sufi terkait ketersambungan silsilah mursyid sebagai syarat

\footnotetext{
${ }^{4}$ Imam Syamsuddin Abi Abdillah bin Qayyim al-Jauzy, al-Roh Libn al-Qayyim, diterjemahkan oleh Jamaluddin Kafi dengan judul Masalab Roh, (Surabaya: PT. Bina Ilmu, 1979.), h. 21-23.

${ }^{5}$ al-Jauzy, al-Roh Libn al-Qayyim h. 24.

${ }^{6}$ al-Jauzy, al-Roh Libn al-Qayyim, h. 20.

7al-Jauzy, al-Rob Libn al-Qayyim, h. 21.

${ }^{8}$ al-Jauzy, al-Roh Libn al-Qayyim, h. 24.
} 
kemuktabarahan sebuah tarekat. Dalam tarekat, mursyid seharusnya murid langsung guru sebelumnya sampai kepada Rasulullah. Kenyataan terkadang tidak demikian, seperti adanya dua mursyid berurutan silsilah namun tidak pernah bertemu, karena yang pertama wafat sebelum yang kedua lahir, atau karena berjauhan tempat tinggal. Mereka beralasan bahwa hal tersebut bisa saja terjadi melalui komunikasi spiritual, yaitu pertemuan dalam wujud rohani yang dalam dunia sufi disebut liqa barzakbi (pertemuan di alam barzakb/rohani) atau disebut juga uwaisi? Syekh Ahmad al-Tijani Pimpinan Tarekat al-Tijaniyah, pernah berjumpa dengan roh Rasululah dan menerima pelajaran dari beliau, sehingga tidak ada mursyid yang menyelinginya antara beliau dengan Nabi Muhammad saw. padahal melintasi jarak sekitar 12 abad. KH. Abd. Muin Hidayatullah (Alm) selaku Pimpinan Tarekat Sufiyah Islam Banjarmasin mengaku pernah dijemput rombongan orang-orang suci dan tokoh-tokoh rohani, terdiri dari Nabi Musa, Nabi Adam, Nabi Muhammad saw. dan tokoh-tokoh dari 40 Negara Islam. Dibawa ke pusat alam gaib di Gunung Pematang di sekitar Gunung Keramaian Pelaihari Kabupaten Tanah Laut (Tala). Penjemputan tersebut dalam rangka peleburan berbagai tarekat yang ada di dunia Islam menjadi satu tarekat saja yaitu 'Tarekat Sufiyah Islam'. Ketika di alam rohani itu ia bertemu dengan roh Rasulullah, roh Nabi Adam, roh Nabi Musa dan roh sejumlah tokoh Negara Islam. Sekaligus ketika itu ia dibai'at sebagai Mursyid Tarekat Sufiyah Islam ini secara labiriyah (z̧hahir, dan pimpinan batinnya adalah Rasulullah. ${ }^{10}$ Mulanya KH. Abd. Muin Hidayatullah merasa tidak sanggup menerimanya seraya mengemukakan alasan ketidak-sanggupannya. Namun menurutnya semua makhluk gaib yang ada saat itu termasuk Nabi Musa, Nabi Adam, Nabi Muhammad saw. sepakat mendaulat dan membai'atnya sebagai Pimpinan (Mursyid) Tarekat Sufiyah Islam secara labiriyah itu. Mereka mendaulat dan membai'atnya dengan bersama-sama membaca syahadatain sehingga resmilah ia menjadi mursyid tarikat ini. ${ }^{11}$

Prof. Dr. KH. Ahmadi Isa, MA, Guru Besar/Dosen Tarekat Pascasarjana IAIN Antasari Banjarmasin mengakui kemungkinan terjadinya pertemuan liqabarzakhi atau uwaisi yang sifatnya di luar jangkauan rasio itu. Antar tokoh katanya bisa saja terjadi pertemuan demikian di alam rohani itu, dan bisa menghasilkan sesuatu yang bersifat fisik. Syekh Abd. Qadir Jailani pernah menghadiahi jubah kepada Syekh Samman al-Madani, padahal antara keduanya tidak pernah bertemu secara fisik karena berjauhan masa hidupnya. ${ }^{12}$ Dikatakan bahwa sebagian sufi tidak menolak kemungkinan adanya wali yang menerima pelajaran dari guru tanpa melalui komunikasi langsung, kecuali melalui komunikasi spiritual, atau pertemuan secara rohaniah yang disebut dengan liqa barzakhi (pertemuan di alam barzakb) atau uwaisi ${ }^{13}$ itu. Kalau demikian halnya maka pertemuan HA dengan roh para Syekh Timur Tengah (STT) yang bermakam di Kabupaten Tabalong Tanjung dan dengan roh-roh gaib lainnya yang berkomunikasi dengannya, diasumsikan sebagai liqa barzakhi atau unaisi itu, melalui mimpi atau lainnya, meski pun hal ini memerlukan kajian yang lebih mendalam.

'al-Jauzy, al-Rob Libn al-Qayyim, h. 24.

${ }^{10}$ Murjani Sani, Tarekat Sufiyah Islam dalam Pemikiran TasamufKH. Abdul Muin Hidayatullah,Tesis S2, (Banjarmasin: IAIN Antasari, 2006.), h. 126.

${ }^{11}$ Murjani Sani, Tarekat Sufiyah, h. 127.

${ }^{12}$ Kuliah Pascasarjana IAIN Antasari, 29 September 2005.

${ }^{13} \mathrm{Hj}$.Sri Mulyani, et al, Mengenal dan Memabami Tarekat-Tarekat Muktabarah di Indonesia, Edisi I Jakarta: Pranada Media, 2004.), Cet. Ke-I, h. 9-10. 


\section{Penutup}

Makam para STT di Kabupaten Tabalong Tanjung mulanya hanya Alkah Datu Harung cs. Karena dianggap kubur tua (baca: keramat) ia pun sering diziarahi warga. Tahun 2000 kubur Datu Harung cs. itu dipindah ke tempat lain, dan lokasinya dijadikan alkah makam STT yang dipindah ke daerah ini. Alkah/makam tersebut ditempati roh mereka, sementara jasadnya tetap berada di negara asalnya. Perpindahan makam ini dilakukan oleh HA sebagai mediatornya (Penggagas/Pengelola) yang mengaku bisa dan dapat berkomunikasi dengan roh-roh gaib dan 'badangsanakan' dengan tokoh-tokoh sufi secara rohani. Kepindahan roh-roh STT ke daerah ini berdasar keinginan mereka sendiri, sehingga di bawah 23 bangunan yang berhias kain kuning, terdapat 48 buah makam selaku Pimpinan STT lengkap dengan nama asal daerah dan jabatan/ pekerjaan saat masih hidup. Kecuali itu ada enam kubur masyarakat biasa tanpa bangunan dari keluarga HA sendiri.

Tidak ada struktur pengelolaan makam STT ini, kecuali HA selaku Penggagas, Pengelola/ Mediatornya, ditambah dua orang Anggota/Pembantunya. Pengelolaannya semata-mata untuk mengayomi roh para ST'T dan melanggengkan hubungan rohani dengan mereka, selain sebagai tambahan tempat wisata religi bagi daerah dan membantu kenyamanan penziarah. Biaya pengelolaan ditanggungnya sendiri sehingga tidak ada motivasi yang bertendensi ekonomi di dalamnya. Penziarah yang terdiri dari warga setempat dan beberapa di antaranya berasal dari luar daerah,dalam ziarahnya tidak tampak adanya prilaku 'menyimpang' dengan catatan kondisi/ sikap batinnya tergantung individu masing-masing.

Pertemuan HA selaku Penggagas/Pengelola makam dengan roh para STT ini, ada kemiripan dengan pertemuan manusia yang hidup dengan roh manusia yang sudah meninggal dunia. Berdasar kajian teoritis ketasawufan hal itu bisa saja terjadi, sehingga pertemuan tersebut mirip liqa barzakbi (pertemuan di alam barzakb) atau uwaisi dalam dunia tasawuf.

\section{DAFTAR PUSTAKA}

Al-Qur'an al-Karim

Al-Banjari, Syekh Muhammad Arsyad, (tth). Sabilal Mubtadin Li al-Tafaqquh fi Amr al-Din, Mesir: Dar al-Ihya al-Kutub al-Arabiyah.

Bruinessen, Martin van, (1999). Tarekat Naqsyabandiyah di Indonesia, Cet. Ke-IV, Jakarta:Mizan, Al-Jauzy, Imam Syamsuddin Abi Abdillah bin Qayyim, (1979). al-Roh Li Ibn al-Qayyim, diterjemahkan oleh Jamaluddin Kafi dengan judul Masalah Roh, Surabaya: PT. Bina Ilmu.

Muslim, Imam, (tth). Shabih Muslim, Bandung: Syirkah al-Ma'arif li al-Thaba' wa al-Nasyr.

Mulyati, Hj. Sri, et al, (2004). Mengenal dan Memahami Tarekat-Tarekat Muktabarah diIndonesia, Edisi I,Cet. Ke-I, Jakarta: Pranada Media.

Sani, Murjani, (2006). Tarikat Sufiyah Islam dalam Pemikiran Tasawuf KH. Abdul Muin Hidayatullah (Tesis S2), Banjarmasin: Institut Agama Islam Negeri Antasari. 